\title{
Production Performance of TANUVAS Aseel Poultry Breed in Western Zone of Tamil Nadu, India
}

\author{
S. Vinothraj*, P. Alagesan, P. Pachiappan, S. Saravanakumar, \\ M. Siva and R. D. Srinivasan
}

ICAR - Krishi Vigyan Kendra (Myrada), Erode District, Tamilnadu, India

*Corresponding author

\begin{tabular}{|c|c|}
\hline & A B S T R A C T \\
\hline Keywords & \multirow{4}{*}{$\begin{array}{l}\text { This study was conducted to evaluate the production performance of TANUVAS } \\
\text { Aseel in Western Zones of Tamil Nadu. } 150 \text { Day old TANUVAS Aseel chicks were } \\
\text { obtained from TANUVAS-CPPM, Hosur and distributed to farmers in different blocks } \\
\text { of Erode district. Body weight and Egg production parameters were recorded in } \\
\text { farmer's field at weekly interval upto } 72 \text { weeks of time. The traits studied were body } \\
\text { weight, Average age at first egg, Livability, Egg weight egg production and body } \\
\text { measurements. The mean values and standard errors of } 20 \text { th week body weight, Age } \\
\text { at First egg and Egg production ( } 20-40 \text { weeks) were, } 943 \pm 07.82 \mathrm{~g}, 33.6 \pm 0.17 \mathrm{~g} \text { and } \\
182 \pm 2.34 \text { days and } 146 \pm 4.88 \text { respectively. The study was concluded that observed } \\
\text { productive performance TANUVAS Aseel can serve as an alternate improved strain to } \\
\text { boost up the backyard farming. }\end{array}$} \\
\hline 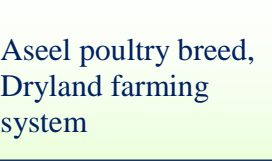 & \\
\hline Articl & \\
\hline $\begin{array}{l}A c \\
18 \\
A v \\
10\end{array}$ & \\
\hline
\end{tabular}

\section{Introduction}

Backyard poultry production is one of the important aspects in dryland farming system, this enterprise plays a major role in livelihood of poor farm families. Even though, agriculture is the major activity, the income derived from agriculture is not so desirable due to climate change and high input cost. So, the farmers turned to allied activities like Dairy farming, Sheep \& Goat farming and Backyard poultry farming etc. The consumption of Desi bird meat \& eggs among people is increasing trend, hence great scope for landless \& small farmers to start backyard poultry farming in rural and semi-urban areas.
The production performance of native breeds is low and high incidence of diseases. The backyard poultry production can be enhanced with improved strains such as Gramapriya, Srinidhi, and TANUVAS Aseel etc. Taking these factors into account, we designed our study by introducing TANUVAS Aseel to farmers to assess the production performance of quails in Erode district.

\section{Materials and Methods}

The present study was conducted by ICAR Krishi Vigyan Kendra, Erode district- Tamil Nadu through Front Line Demonstration (FLD) to Study the Production Performance 
of TANUVAS Aseel Chicken Variety. Straight run 150 day-old chicks of TANUVAS Aseel were obtained from College for Poultry Production and Management, Hosur. On arrival, all chicks were provided electrolytes and vitamin supplements in clean drinking water and distributed to the farmers. The brooding was carried out for a period of 21 days ( 3 weeks) using electric bulbs as sources of heat and illumination. Chicks were brooded at a temperature of $35^{\circ} \mathrm{C}$ with adequate water and feeding spaces provided. Light was provided for 24 hours during brooding to avoid pilling and death. Standard management and healthcare practices were followed throughout the experimental period and chick starter ration was provided to the chicks up to 4 weeks of age. Subsequently, the grower ration during growing periods was provided.

The identified Backyard Poultry farmers were trained all scientific practices in Poultry farming and supported with 4 weeks old birds. The demonstrated fields were regularly monitored and periodically observed. The production parameters of Body weight, Feed Conversion ratio, Livability Percentage, Age at First Egg, Egg Production (20-40 Weeks), Egg Weight (Grams) and Hatchability
Percentage were recorded at regular intervals. To study the impact of frontline demonstrations, data from FLD and farmers practices were analyzed. The mean and SE for various traits was calculated according to standard statistical procedures (Snedecor and Cochran, 1994).

\section{Results and Discussion}

The mean values and their standard errors of the production parameters of TANUVAS Aseel shown in Table 1. The Average body weight at 20 weeks of age reported in this present study is comparable with the results reported by Thangadurai and Shanmugam (2019). Neck length, Thigh length, drumstick and shank length at 20 th week is observed in the present study was $21.23 \pm 1.23 \mathrm{~cm}, 10.13$ $\pm 1.46 \mathrm{~cm}, 14.93 \pm 0.62 \mathrm{~cm}$ and $10.21 \pm 1.22$ $\mathrm{cm}$ respectively. Similar result was reported by Haunshi et al., (2011) and Ezhil Valavan et al., (2016). Percentage of Livability (0-12 weeks) was recorded in our study was 96.23. However, Ezhil Valavan et al., (2016) observed that Livability of Aseel was 94.29. Slight differences in Livability due to environmental variation of study location (Table 2).

Table.1 Production performance of TANUVAS Aseel

\begin{tabular}{|l|l|l|}
\hline S. No. & Parameters & \\
\hline $\mathbf{1 .}$ & Body weight (Grams) & $392 \pm 0.46$ \\
\hline & 8 th week & $697 \pm 08.48$ \\
\hline & 12 th week & $943 \pm 07.82$ \\
\hline & 20 th week & \\
\hline 2. & Livability (\%) 0-12 Weeks & 96.23 \\
\hline 3. & Age at First Egg & $182 \pm 2.34$ \\
\hline $\mathbf{4 .}$ & Egg Weight (Grams) & $52.34 \pm 0.96$ \\
\hline $\mathbf{5 .}$ & Egg Production \% (20-40 Weeks) & $146 \pm 4.88$ \\
\hline 6. & Feed Conversion Ratio & $2.92 \pm 4.88$ \\
\hline
\end{tabular}


Table.2 Body measurements of TANUVAS Aseel

\begin{tabular}{|l|l|}
\hline Neck Length $(\mathbf{c m})$ & $\mathbf{2 1 . 2 3} \pm \mathbf{1 . 2 3}$ \\
\hline Thigh Length $(\mathbf{c m})$ & $10.13 \pm 1.46$ \\
\hline Drumstick $(\mathbf{c m})$ & $14.93 \pm 0.62$ \\
\hline Shank Length $(\mathbf{c m})$ & $10.21 \pm 1.22$ \\
\hline
\end{tabular}

In our present study, age at first egg was 182 \pm 2.34 days. In contrary to present finding, age at first egg was slightly lower in the study of Haunshi et al., (2011) and Thangadurai and Shanmugam (2019). However, Ezhil Valavan et al., (2016) reported age at first egg production was 159 days. This might be due to the genetic potentiality of birds, growing stage of the birds, managemental differences and study location. Egg production determining the success of Poultry enterprises and gaining better income to farmers (Vinothraj et al, 2019).

Average Egg production was recorded in the study was 146 at 20-40 weeks These values are agreement with the results by Ezhil Valavan et al., (2016) and Thangadurai and Shanmugam (2019). However, Vinothraj et al., (2019) reported 182 eggs /year under deeplitter system for the TANUVAS Aseel breed.

From the results, it could be concluded that production performance of TANUVAS Aseel were comparable with the earlier reports on quails. The average body weight, Age at First egg production and Annual Egg production are found to be similar in all field levels but mild differences between reported estimates for production performance may depend on the Genetic makeup, environmental conditions and Mangement in the study areas. TANUVAS Aseel breed had better market opportunity and farmers adoption due its external appearance and genetic potentiality. So, farmers from rural areas of Erode district can rear TANUVAS Aseel for their livelihood and nutritional security.

\section{References}

Vinothraj, S., P. Alagesan and Siva, M. 2019. Assess the Performance of Different Breeds under Backyard Poultry Farming System in Erode District. Int.J.Curr.Microbiol.App.Sci. $\quad$ 8(09): 1138-1141. doi: https://doi.org/10.20546/ijcmas.2019.809 .130

Haunshi, S., M. Niranjan, M. Shanmugam, M. K. Padhi, M. R. Reddy, R. Sunitha, U. Rajkumar and A. K. Panda, 2011. Characterization of two Indian native chicken breeds for production, egg and semen quality, and welfare traits. Poul. Sci., 90: 314-320

Thangadurai, R and P.S. Shanmugam 2019. Comparative performance of TANUVAS Aseel. Gramapriya and Indigenous Desi bird under Backyard Condition in Dharmapuri District. Indian Vet. J., December 2019, 96 (12):33-35

Ezhil Valavan, S., A.V. Omprakash, A. Bharatidhasan and V. Ramesh Saravana Kumar. 2016. Production Performance of Aseel Under Indian Tropical Condition. International Journal of Applied and Pure Science and Agriculture, 2(11): 107-110

Snedecor, G. W. and Cochran, W. G. (1994) Statistical Methods, 8th Edition, IOWA State University Press, Amos, USA. 


\section{How to cite this article:}

Vinothraj, S., P. Alagesan, P. Pachiappan, S. Saravanakumar, M. Siva and Srinivasan, R. D. 2020. Production Performance of TANUVAS Aseel Poultry Breed in Western Zone of Tamil Nadu, India. Int.J.Curr.Microbiol.App.Sci. 9(09): 2447-2450. doi: https://doi.org/10.20546/ijcmas.2020.909.304 